CARNAL RHETORIC 


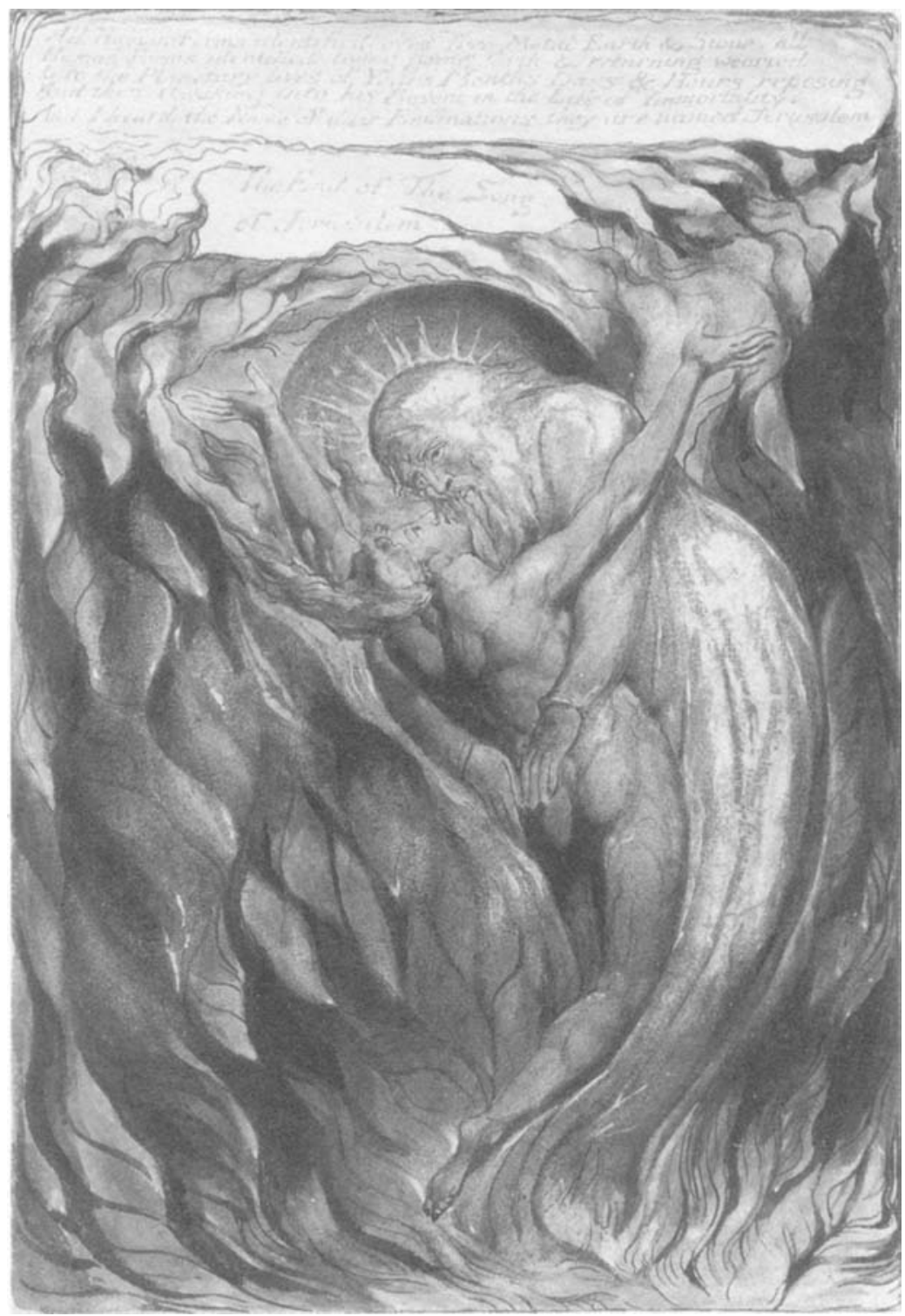

Jerusalem, Plate 99 , by William Blake. Yale Center for British Art, Paul Mellon Collection. 


\title{
CARNAL RHETORIC
}

\section{Milton's Iconoclasm and the Poetics of Desire}

\author{
Lana Cable
}

Duke University Press Durham and London 1995 
(C) 1995 Duke University Press

All rights reserved

Printed in the United States of America on acid-free paper $\infty$ Designed by Cherie Holma Westmoreland

Typeset in Trump Mediaeval with Adobe copperplate display

Chapter 5 is based on "Milton's Iconoclastic Truth," in Politics, Poetics, and Heremeneutics in Milton's Prose, David Loewenstein and James Grantham Turner, eds., (c) Cambridge University Press 1990. Reprinted with the permission of Cambridge University Press. Portions of chapter 3 first appeared in "Coupling Logic and Milton's Doctrine of Divorce," Milton Studies XV, James D. Simmonds, ed., published in $198 \mathrm{I}$ by the University of Pittsbuigh Press. Reprinted by permission of the publisher. Chapter 2 is based on "Shuffling Up Such a God," Milton Studies XXI, James D. Simmonds, ed., published in 1986 by the University of Pittsburgh Press. Reprinted by permission of the publisher.

Library of Congress Cataloging-in-Publication Data appear on the last printed page of this book. 


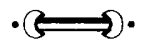

To E. M.

For while I sit with thee, I seem in Heav'n,

And sweeter thy discourse is to my eare

Then Fruits of Palm-tree pleasantest to thirst ....

(Paradise Lost VIII, 210-I2) 
